\title{
The Effect of Water Intake on Body Mass Index in Universitas Sumatera Utara Medical Students
}

\author{
Nenni Dwi Aprianti Lubis ${ }^{1 *(\mathbb{D})}$, Fitriyani Nasution ${ }^{1}$, Hidayat Hidayar $^{2}$, Sri Amelia ${ }^{3}$ D, Ridwan Balatif ${ }^{4}$ \\ ${ }^{1}$ Department of Nutrition, Faculty of Medicine, Universitas Sumatera Utara, Medan, Indonesia; ${ }^{2}$ Department of Biochemistry, \\ Faculty of Medicine, Universitas Sumatera Utara, Medan, Indonesia; ${ }^{3}$ Department of Microbiology, Faculty of Medicine, Universitas \\ Sumatera Utara, Medan, Indonesia; ${ }^{4}$ Faculty of Medicine, Universitas Sumatera Utara, Medan, Indonesia
}

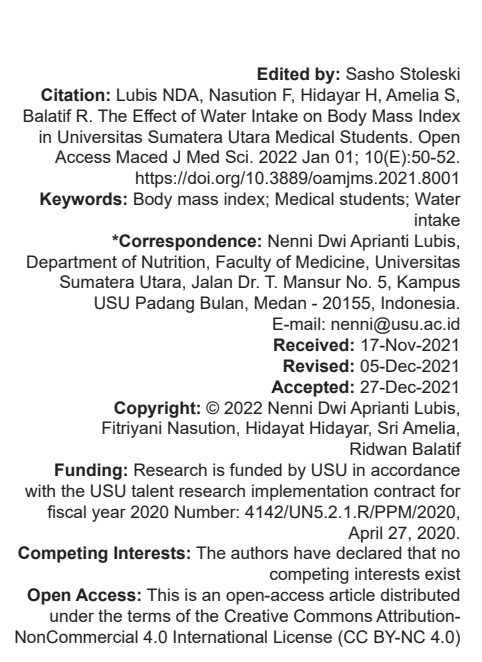

\begin{abstract}
BACKGROUND: Overweight and obesity are one of the health problems in the world. This condition is associated with various health problems such as cardiovascular disease, stroke, osteoarthritis, chronic back pain, gallbladde disease, and cancer. Consuming adequate fluids can help you lose weight. Diarrhea stands as a result of the intervariable relationships, including behavior, environmental aspect, and household states.

AIM: This study aimed to determine the relationship between body fluid intake and body mass index (BMI) in Medical Faculty Universitas Sumatera Utara (USU) students.

METHODS: A cross-sectional study was conducted on USU medical faculty students from October 2020 to January 2021 with a sample of 99 people. Researchers obtained that primary data obtained through reporting daily fluid intake for 7 consecutive days and anthropometric measurements. Furthermore, the researchers conducted the Spearman test to determine the relationship between the two variables.

RESULTS: Based on the characteristics of the sample, the researchers obtained 51 samples that were female $(51.5 \%)$, and 48 were male $(48.5 \%)$ with an average age of $20.05 \pm 1.08$ years. The average fluid intake consumed was around $2070.07 \pm 654.93 \mathrm{~mL} /$ day, whereas 48 people in the study sample consumed less fluid below $2000 \mathrm{~mL} /$ day $(45.5 \%)$. The classification of nutritional status of the sample based on BMI showed that 44 people had normal nutritional status $(44.4 \%), 48$ people were overweight $(48.5 \%)$, and seven people were obese $(7.1 \%)$

CONCLUSION: The test results showed a significant relationship between daily fluid intake and BMI $(p=0.007)$.
\end{abstract}

\section{Introduction}

Overweight and obesity are some of the health problems in the world. This condition is associated with the emergence of various diseases such as heart and blood vessel disorders, stroke, osteoarthritis, chronic back pain, gallbladder disease, and cancer [1]. Obesity is also strongly associated with a decrease in quality of life, an increase in the treatment used, and the cost of care in health services [2].

From 1975 to 2016 , it is estimated that the incidence of obesity is 3 times higher. In 2016, more than 1.9 billion adults were overweight globally, and 650 million of them were obese. Similarly, in the age group of children and adolescents, more than 340 million are overweight and obese [3]. In Indonesia, based on the 2018 Basic Health Research (RISKESDAS 2018) data, $13.6 \%$ of the population aged $>18$ years are overweight and $21.8 \%$ of the people old $>18$ years were obese. The condition of overweight and obesity in Indonesia continued to increase from 2007, 2013 to 2018 [4]. The state of overweight and obesity may continue to grow in the following year. Therefore, a strategy is needed to prevent the possibility of increasing cases of overweight and obesity.

Consuming adequate fluids can help you lose weight. There are two mechanisms of weight loss through fluid intake, which can reduce appetite and increase lipolysis [5]. The water intake needed by a person varies depending on age, body health conditions (e.g., pregnancy), environment, and occupation. Water intake recommendations also differ from the recommendations between institutions. The European Food Safety Authority (EFSA, 2010) states that the fluid needs of adult men are around $2500 \mathrm{~mL} /$ day, while the National Academy of Medicine (2004) says that the fluid needs of adult men are about $3700 \mathrm{~mL} /$ day [6]. In Indonesia, the Ministry of Health recommends that adequate fluid intake in adults reaches $2000 \mathrm{~mL} /$ day [7]. On this basis, a study was conducted to determine the effect of fluid intake on body mass index (BMI) and body fat. 


\section{Methods}

Researchers conducted a cross-sectional design at the Faculty of Medicine, Universitas Sumatera Utara (USU), in October 2020-January 2021. The Ethical Committee for Research, USU has approved this study with reference number: 69/KEP/USU/2020 on June 15, 2020. Researchers collected the amount and type of fluid intake and nutritional status of each research subject. The population in this study was 748 medical students. Based on the Taro-Yamane [8] formula, 99 people became subjects with a simple random sampling technique.

Researchers collected data through filling and reporting waterintake and anthropometric measurements. The collection of water intake data was carried out for 7 consecutive days through a recall of consumption and writing it using the Google form application designed by the researcher. Subjects reported all types of drinks and food consumed during 1 day. Reporting is carried out every day at 3 times, namely, at $10 \mathrm{am}, 5 \mathrm{pm}$, and 10 pm, through the http://bit.ly/recall_konsumsi page.

Researchers assessed nutritional status referring to BMI based on anthropometric examinations, namely, weight and height measurements. Researchers classified nutritional status based on BMI Asia-Pacific classification in the form of underweight $\left(<18.5 \mathrm{~kg} / \mathrm{m}^{2}\right)$, normal $(18.5-22.9 \mathrm{~kg} /$ $\left.\mathrm{m}^{2}\right)$, overweight (23-24.9 kg/m²), and obesity $\left(25 \mathrm{~kg} / \mathrm{m}^{2}\right)$.

Researchers conducted descriptive data analysis for all variables. Then, researchers tested the relationship between water intake and BMI using Spearman's test.

\section{Results}

\section{Baseline characteristic}

Table 1 showed that from 99 subjects, 48 were male and the rest were female. The mean age of the subjects was $20.08 \pm 1.08$ years

Table 1: Baseline characteristics of the students included in the study

\begin{tabular}{ll}
\hline Characteristics & Total $\mathrm{n}(\%)$ or Mean (SD) \\
\hline Gender & \\
Male & $48(48.50)$ \\
Female & $51(51.50)$ \\
Age & $20.08 \pm 1.08$ \\
\hline
\end{tabular}

\section{Water intake}

On average, the subjects consumed $2070.07 \pm 654.93 \mathrm{~mL}$ of water every day. Based on the adequacy of consumption, a total of $45.5 \%$ of research subjects consumed fewer fluids ( $<2000 \mathrm{~mL} /$ day). The types of drinks that the subjects usually consumed were drinking water $(80.3 \%)$, tea $(5.5 \%)$, milk $(4.7 \%)$, fruit juices $(3.4 \%)$, coffee $(2.2 \%)$, carbonated drinks $(0.8 \%)$, and other beverages such as energy drinks (3.1\%). The average types of beverages consumed by research subjects are listed in Table 2.

Table 2: Subjects water intake

\begin{tabular}{ll}
\hline Characteristics & Total N $(\%)$ or Mean (SD) \\
\hline Water intake & \\
$\quad$ Adequate & $48(48.50)$ \\
Inadequate & $51(51.5 \%)$ \\
Water quantity in $\mathrm{mL} / \mathrm{day}$ & $2070.07 \pm 654.93$ \\
Types of drinks & \\
Drinking water & $1661.82 \pm 555.28$ \\
Tea & $113.89 \pm 180.66$ \\
Milk & $99.51 \pm 128.62$ \\
Fruit juice & $69.56 \pm 144.39$ \\
Coffee & $44.84 \pm 126.26$ \\
Carbonated drinks & $16.81 \pm 48.20$ \\
Other beverages & $65.82 \pm 107.11$ \\
\hline
\end{tabular}

\section{Nutritional status}

Based on the frequency distribution of nutritional status, it is known that the most of them are overweight and obese (55.6\%) with a mean weight of 64.89 $\pm 15.39 \mathrm{~kg}$ and height of $162.63 \pm 7.95 \mathrm{~cm}$ (Table 3).

Table 3: Subject nutritional status

\begin{tabular}{ll}
\hline Characteristics & Total $\mathrm{n}(\%)$ or Mean (SD) \\
\hline Weight $(\mathrm{cm})$ & $64.89 \pm 15.39$ \\
Height $(\mathrm{kg})$ & $162.63 \pm 7.95$ \\
Nutritional status & \\
$\quad$ Normal & $44(44.40)$ \\
Overweight & $48(48.50)$ \\
Obese & $7(7.10)$ \\
\hline
\end{tabular}

\section{Water consumption and BMI}

Before the researchers tested the two variables, first, the subject's water intake and nutritional status were grouped. Fluid intake was grouped based on the average daily fluid consumption, namely, less (<2000 mL) and sufficient $(\geq 2000 \mathrm{~mL}$ ). Researchers divided nutritional status based on BMI of research subjects according to the Asia-Pacific criteria. Furthermore, researchers used the Spearman correlation test to determine the relationship between the two variables. The analysis results showed a significant relationship between daily fluid intake and BMI $(p=0.007)$, but the effect was not so strong (Table 4).

Table 4: Spearmen correlation analysis of water intake and BMI

\begin{tabular}{lll}
\hline Variables & BMI category & Water intake category \\
\hline BMI & 1.000 & $0.267^{* *}$ \\
Correlation coefficient & & 0.007 \\
Sig (two-tailed) & 99 & 99 \\
N & & \\
Water intake category & $0.267^{* *}$ & 1.000 \\
$\quad$ Correlation coefficient & 0.007 & 99 \\
Sig (2-tailed) & 99 & 99 \\
N &
\end{tabular}

\section{Discussion}

This study found that more than $50 \%$ of medical students were overweight and obese. A previous study 
conducted by Khan et al. (2016) found that almost $21 \%$ of medical students were overweight [9]. The findings of this overweight and obesity condition exceeded the proportion of overweight and obesity in people aged $>18$ years nationally based on RISKESDAS 2018 [4]. The occurrence of overweight in research subjects is possible because of the COVID-19 pandemic, which causes learning activities to be carried out only from home. Since this pandemic, the sedentary lifestyle has increased and physical activity has decreased [10].

In terms of fluid intake, almost $50 \%$ of medical students do not consume enough fluids. It is feared that this lack of fluid will lead to dehydration. Conditions of $1-2 \%$ fluid deficiency will increase thirst, fatigue, and loss of appetite. When the body loses body fluids by $3-4 \%$, it will decrease urine production, dry skin and mouth, apathy, and impaired physical performance. Loss of body fluids by $5-6 \%$ will cause impaired concentration, headaches, increased respiratory rate, irritability, and temperature disturbances [11]. This lack of fluid intake can result in a decrease in the quality of student learning.

From the analysis of the relationship between daily water intake and BMI, it was found that the results were significant but did not have a strong correlation. The study by Garcia et al. (2019) found that fluid intake did not have a substantial relationship with BMI, but fluid intake had an influence in normalizing body weight, body fat, and waist circumference [12].

Theoretically, water consumption can help weight loss. When a person consumes water before breakfast, it will slow down gastric emptying to trigger feelings of fullness and reduce hunger. In addition, food intake will also decrease when drinking water before breakfast [13]. Water consumption can also stimulate the sympathetic nerves to increase metabolic rate, such as triggering thermogenesis and increasing energy expenditure. Metabolism of fat into energy requires the help of water so that if you consume less water, fat metabolism will decrease and cause a slowdown in weight loss [14].

\section{Conclusion}

We concluded that fluid intake had a relationship with $\mathrm{BMI}$.

\section{References}

1. Balatif R, Lubis ND. Obesitas dengan kanker kolorektal, bagaimana keterkaitan keduanya. Scripta. 2021;2(2):116-22. https://doi.org/10.32734/scripta.v2i2.4399

2. Djalalinia S, Qorbani M, Peykari N, Kelishadi R. Health impacts of obesity. Pak J Med Sci. 2015;31(1):239-42. https://doi. org/10.12669/pjms.311.7033

PMid:25878654

3. World Health Organization. Obesity and Overweight, Key Facts. Geneva: World Health Organization; 2021. Available from: https://www.who.int/news-room/fact-sheets/detail/obesity-andoverweight [Last accessed on 2021 Sep 21].

4. Kementerian Kesehatan Republik Indonesia, Hasil Utama Riskesdas; 2018. Available from: https://www.kesmas. kemkes.go.id/assets/upload/dir_519d41d8cd98f00/ files/hasil-riskesdas-2018_1274.pdf [Last accessed on 2021 Sep 01].

5. Thornton SN. Increased hydration can be associated with weight loss. Front Nutr. 2016;3:18. https://doi.org/10.3389/ fnut.2016.00018

PMid:27376070

6. Armstrong LE, Johnson EC. Water intake, water balance, and the elusive daily water requirement. Nutrients. 2018;10(12):1928. https://doi.org/10.3390/nu10121928

PMid:30563134

7. Kementerian Kesehatan Republik Indonesia. Berapa Takaran Normal Agar Tubuh Tidak Kekurangan Cairan; 2021. Available from: https://www.p2ptm.kemkes.go.id/ infographic-p2ptm/hipertensi-penyakit-jantung-danpembuluh-darah/page/5/berapa-takaran-normal-agartidak-kekurangan-cairan-dalam-tubuh [Last accessed on 2021 Sep 01].

8. Adam AM. Sample size determination in survey research JSRR. 2020;26(5):90-7. https://doi.org/10.9734/JSRR/2020/ v26i530263

9. Khan ZN, Assir MZ, Shafiq M, Chaudhary AE, Jabeen A. High prevalence of preobesity and obesity among medical students of Lahore and its relation with dietary habits and physical activity. Indian J Endocrinol Metab. 2016;20(2):206-10. https:// doi.org/10.4103/2230-8210.176357

PMid:27042417

10. Stockwell S, Trott M, Tully M, Shin J, Barnett $\mathrm{Y}$, Butler $\mathrm{L}$, et al. Changes in physical activity and sedentary behaviours from before to during the COVID-19 pandemic lockdown: A systematic review. BMJ Open Sport Exerc Med. 2021;7:e000960. https:// doi.org/10.1136/bmjsem-2020-000960 PMid:34192010

11. Whitney E, Rolfes SR. Understanding Nutrition. $15^{\text {th }}$ ed. Boston: Cengage Learning; 2019.

12. Laja García Al, Moráis-Moreno C, Samaniego-Vaesken ML, Puga AM, Partearroyo T, Varela-Moreiras G. Influence of water intake and balance on body composition in healthy young adults from Spain. Nutrients. 2019;11(8):1923. https://doi.org/10.3390/ nu11081923

PMid:31443311

13. Jeong JN. Effect of pre-meal water consumption on energy intake and satiety in non-obese young adults. Clin Nutr Res. 2018;7(4):291-6. https://doi.org/10.7762/cnr.2018.7.4.291 PMid:30406058

14. Vij VA, Joshi AS. Effect of 'water induced thermogenesis' on body weight, body mass index and body composition of overweight subjects. J Clin Diagn Res. 2013;7(9):1894-6. https://doi.org/10.7860/JCDR/2013/5862.3344

PMid:24179891 